\title{
Resistant starch, amylose, and amylopectin content in breadfruit cookies as an alternative snack for individuals with diabetes mellitus
}

\author{
Fitriani, Z.A., *Dieny, F.F., Margawati, A. and Jauharany, F.F. \\ Department of Nutrition Science, Faculty of Medicine, Universitas Diponegoro, Indonesia
}

\begin{abstract}
Article history:
Received: 1 August 2020

Received in revised form: 9

September 2020

Accepted: 9 November 2020

Available Online: 7 February 2021
\end{abstract}

\section{Keywords:}

Cookies,

Breadfruit,

Amylopectin,

Amylose,

Resistant Starch,

Diabetes

\section{DOI:}

https://doi.org/10.26656/fr.2017.5(1).418

\begin{abstract}
Uncontrolled hyperglycaemia in individuals with diabetes mellitus can increase the risk factors for disease complications. Therefore, lifestyle management becomes a vital measure for those individuals, especially in diet management, to control their blood sugar level. Breadfruit starch-based cookies contain resistant starch, amylose, and amylopectin that can inhibit the increment of blood sugar levels. Hence, these cookies can be used as an alternative snack for those individuals. This study was aimed to analyse the content of resistant starch, amylose, and amylopectin, as well as the acceptability level of breadfruit starch-based cookies. We used a completely randomised experiment using four formulations with various breadfruit flour content: $25 \%, 50 \%, 75 \%$ and $100 \%$. The breadfruit formulation containing breadfruit flour (BF) and wheat flour (WF). Formula $25 \%$ (25\% BF $75 \% \mathrm{WF}, 50 \%$ (50\% BF and WF), $75 \%$ (75\% BF $25 \% \mathrm{WF}$ ), and $100 \% \mathrm{BF}$. The one-way ANOVA was used to compare the content of resistant starch, amylose, and amylopectin among the cookies. Furthermore, the Friedman test was used to analyse the acceptance level of the cookies, which includes colour, odour, texture, and flavour. The cookies contain $19.38-20.51 \%$ of resistant starch, $13.55-16.60 \%$ of amylose, and 83.39 $86.44 \%$ of amylopectin. The highest resistant starch and amylose contents were found in cookies with $100 \%$ breadfruit flour content, while the highest amylopectin content was found in the $25 \%$ formulation. The acceptability level of the cookies included colour, odour, texture, and flavour. Cookies made with $100 \%$ breadfruit flour contained the highest resistant starch and amylose, but the lowest amylopectin. It also received the highest acceptability among the panellists.
\end{abstract}

\section{Introduction}

Diabetes mellitus (DM) is a metabolic disease indicated by high blood sugar level due to impaired insulin secretion, the disruption of insulin action, or both. $\mathrm{DM}$ is closely related to tissue impairments such as impairments in kidneys, eyes, neural system, heart, and blood vessels if the disease remains untreated for a long time (American Diabetes Association, 2011). Nowadays, the prevalence of DM is relatively increasing. Based on Data Riset Kesehatan Dasar (Riskesdas) Indonesia 2018, The national prevalence of DM cases as specified by the symptoms and diagnoses in the population of age $>15$ years old, increased from $6.9 \%$ in 2013 to $8.5 \%$ in 2018 (Kementerian Kesehatan RI, 2013; Kementerian Kesehatan RI, 2018). The World Health Organization (WHO) even predicts that diabetes mellitus will afflict more than 21 million Indonesians in 2030 (World Health Organization, 2016).
According to the International Diabetes Federation, 382 million of adults around the world $(8.3 \%)$ had diabetes and $80 \%$ of them residing in low and middleincome countries. If the trend continues, 592 million or a tenth of the adult population will suffer from DM (International Diabetes Federation, 2012). Indonesia is ranked one of the top ten countries with DM worldwide, after the European countries, the United States, and China. Individuals with DM in Indonesia are increasing; $90-95 \%$ of them is type 2 DM. The World Health Organization has predicted that the number of diabetics in Indonesia will continue to grow and reach about 21.3 million in 2030 (Wild et al., 2004).

Lifestyle modifications take a crucial part for diabetics, especially to help them control their blood sugar level and to lower the risk of further complications. Dietary management is one of the modifications that can affect the blood sugar level, which can be achieved by 
choosing the correct amount and type of carbohydrates consumed. Selecting the right food ingredients has become the scientific basis for determining the glycaemic response in a person. Carbohydrates that are recommended for individuals with DM are complex carbohydrates or polysaccharides, especially resistant starch.

Resistant starch is a form of starch that resists digestion due to its compact molecules preventing its breakdown by the digestive enzymes, thus avoiding blood sugar spikes (Fuentes-Zaragoza et al., 2010; Herawati, 2011). One food ingredient that contains high resistant starch, amylose, and amylopectin is breadfruit. It is widely available in Indonesia and has a unique taste. Per $100 \mathrm{~g}$ of breadfruit contains $100 \mathrm{kcal}$ of energy, $1.3 \mathrm{~g}$ of protein, $0.3 \mathrm{~g}$ of fat, and $2.2 \mathrm{~g}$ of fibres (Adinugraha and Kartikawati, 2012). Moreover, breadfruit contains low-digestible starch compared to the starch in rice, corns, and other tubers which is advantageous to lower blood sugar and blood insulin level (Landon et al., 2012).

Breadfruit is one of the local staple foods that contains lower calories compared to rice, potatoes, and sweet potatoes. It has approximately $3.25 \%$ higher of resistant starch content compared to sweet potatoes, potatoes, and wheat (Rosida and Yulistyani, 2013). In flour form, the resistant starch in breadfruit is $23.6 \%$ more than rice, $24.2 \%$ more than corn, $20.6 \%$ more than cassava, $31.5 \%$ more than potatoes, and $26.5 \%$ more than wheat (Septianingrum et al., 2016).

However, despite the benefits it offers, the fruit has not been put to good use due to its poor shelf life. Therefore, to manage this problem, the fruit is often converted into flour. This flour form is expected to have a longer shelf life as well as to increase its possibility to be processed into other foods. Breadfruit flour has a low glycaemic index (GI) which is favourable to be an alternative food source for diabetics.

There is a growing interest in the utilisation of breadfruit in a wide range of products since breadfruit contains an appreciable amount of resistant starch that could lower the glycaemic and insulin responses. A study by Noor et al. showed that breadfruit flour had higher crude fibre of $4.85 \%$ than commercial wheat flour, which contained $0.23 \%$ crude fibre (Siti Nuriah et al., 2018). Another study by Zakaria found that the 5\% substitution of breadfruit resistant starch in bread formulation gave a lower GI value of 76 than GI value of 97 showed by control bread (Zarinah et al., 2018). Turi et al. (2015) conducted a study to review the nutritional profile of breadfruit and found that cooked breadfruit has low to moderate GI which is a potential to be used in controlling diabetes.

As breadfruit flour is easier to process, a variety of foods has been produced. One of them is breadfruit cookies. The cookies are expected to have a longer shelf life due to its low water content (4\%) compared to other processed foods such as brownies, cakes, sponge cakes, or compared to deep-fried and steamed breadfruit. Other than that, the cookies are easier to make and to carry around (Dewi et al., 2010). The breadfruit cookies are also expected to have high public acceptability, hopefully among individuals with DM, thus increasing its economic value.

According to the abovementioned background, this study aims to investigate the content of resistant starch, amylose, and amylopectin in breadfruit cookies as an alternative snack for individuals with DM.

\section{Materials and methods}

\subsection{Study design, location, and time}

This research falls into food production category. It was conducted from August to September 2017. The analyses of resistant starch, amylose, and amylopectin were performed in the Centre for Food and Nutrition Studies, Universitas Gadjah Mada, Yogyakarta. Furthermore, the acceptability test of the cookies was carried out in the Department of Nutrition Science office, Universitas Diponegoro, Semarang.

\subsection{Materials}

The breadfruit flour used in the recipe is made of the white breadfruit type that is widely available in the market. The white breadfruit was selected because it produced flour with the same colour as wheat flour. We obtained the other ingredients such as eggs, vanilla, salt, baking powder, margarine, and stevia at Toko Semarang. The utensils used were a mixer, a blender, a sieve, spatulas, bowls, a scale, knives, an oven, and spoons. The process includes breadfruit flour production, ingredient mixing, and dough cutting.

\subsection{Methods}

This research is a completely randomized experiment using four formulations with various breadfruit content: $25 \%, 50 \%, 75 \%$, and $100 \%$. The percentage of formulation of breadfruit flour and wheat flour is determined based on optimization of nutritional content of breadfruit flour cookies that are eligible for biscuits according to SNI (Standard Nasional Indonesia). F100 is a formulation of breadfruit flour $100 \%(100 \mathrm{~g})$, F75 consists of breadfruit flour 75\% (75 g) and wheat 
flour 25\% (25 g), F50 is a formulation breadfruit flour and wheat flour, each equal to $50 \%(50 \mathrm{~g})$ and $\mathrm{F} 25$ consist of $25 \%(25 \mathrm{~g})$ breadfruit flour and $75 \%(75 \mathrm{~g})$ wheat flour. A preliminary experiment was carried out to produce the four variants of the cookies. To make the cookies, eggs and margarine were mixed followed by vanilla, salt, baking powder, sugar and the breadfruit formulation containing breadfruit flour and wheat flour. All the ingredients were blended and homogenized using a mixer for about 5-10 mins. After a homogenous dough had formed, the dough was shaped by a cookie-cutter. The last step was baking the cookies in an oven at approximately $150^{\circ} \mathrm{C}$ for $25-30$ mins. The sugar type used in the cookies was stevia, a special type of sugar for people with DM. The nutrient content of snacks per portion usually covers $10 \%$ of the daily energy requirement. Snacks are usually consumed 2-3 times per day, and therefore provide $200 \mathrm{kcal}$ of energy, $25 \mathrm{~g}$ of carbohydrate, $6.7 \mathrm{~g}$ of fat, and $10 \mathrm{~g}$ of protein.

The method used for the determination of resistant starch was done using the method proposed by Goñi et al. (1992). The amylose content was determined using the colorimetric iodine method, while the amylopectin content was estimated by different calculation 14. All the content analyses were run three times.

\subsection{Organoleptic testing}

The acceptability of the breadfruit cookies was examined by the hedonic test using four rating scales: 1 $=$ Dislike a lot, $2=$ Dislike a little, $3=$ Like a little, and 4 $=$ Like a lot. We selected twenty-five slightly trained panellists from the Department of Nutrition Science Universitas Diponegoro. These panellists were students who were in their 5 th or 7 th semester and had completed their course on food acceptability. We chose slightly trained panellists because they were more approachable and more efficient in terms of cost and time compared to trained panellists. The trained panellists have to complete a series of training and pass the examination, which may require more time and cost allocation.

The selection of panellists was started with an interview. The interview aimed to identify candidates' background, health status, and their willingness to participate as a panellist. We then performed a screening test to examine their commitment, openness, honesty, and general knowledge on the sensory panellists. The organoleptic analysis was carried out in Room 304, located on the third floor of the Department of Nutrition Science, Universitas Diponegoro, Semarang. The organoleptic test was carried out in a room far from the food storage area, in order not to disturb the panelists' sensory. Every panellist received $5 \mathrm{~g}$ of cookies from each formulation: F25, F75, F50 and F100. All cookies given had the same size. Moreover, the ID assigned to each cookie had been made unique to prevent the panellists from guessing the cookie's contents. We avoided using a subsequent coding method such as A, B, $\mathrm{C}$ or 1, 2, 3 that might lead the panellist to give a high rating based on the code order 15 . In this research, we used three digits random codes: 283, 125, 608, and 479 .

\section{Results and discussion}

The breadfruit cookies contained $19.38-20.51 \%$ of resistant starch, $13.55-16.60 \%$ of amylose, and 83.39$86.44 \%$ of amylopectin. The analysis results show that there are significant differences in the contents of resistant starch, amylose, and amylopectin among the four cookie formulations.

Table 1 shows the significant differences of resistant starch, amylose and amylopectin contents among the formulations. The resistant starch was found the highest in the $100 \%$ formulation, while the lowest in the $25 \%$. Similar results were also observed in the amylose contents. However, the amylopectin content was quite the opposite. The $25 \%$ formulation contained the highest amylopectin, while $100 \%$ contained the least.

Table 1. The contents of resistant starch, amylose, and amylopectin per $100 \mathrm{~g}$ of breadfruit cookies

\begin{tabular}{lccc}
\hline Formulation & $\begin{array}{c}\text { Resistant starch } \\
(\%)\end{array}$ & $\begin{array}{c}\text { Amylose } \\
(\%)\end{array}$ & $\begin{array}{c}\text { Amylopectin } \\
(\%)\end{array}$ \\
\hline F25 & $19.38 \pm 0.15$ & $13.55 \pm 0.03$ & $86.44 \pm 0.03$ \\
F50 & $19.57 \pm 0.17$ & $14.26 \pm 0.01$ & $85.73 \pm 0.01$ \\
F75 & $20.03 \pm 0.03$ & $15.88 \pm 0.02$ & $84.11 \pm 0.02$ \\
F100 & $20.51 \pm 0.09$ & $16.60 \pm 0.04$ & $83.39 \pm 0.04$ \\
\hline & $\mathrm{p}=0.001$ & $\mathrm{p}=0.000$ & $\mathrm{p}=0.000$ \\
\hline
\end{tabular}

The acceptability of the breadfruit cookies was examined by the hedonic test or the preference test with panellists. The test results are shown in Table 2 and Figure 1.

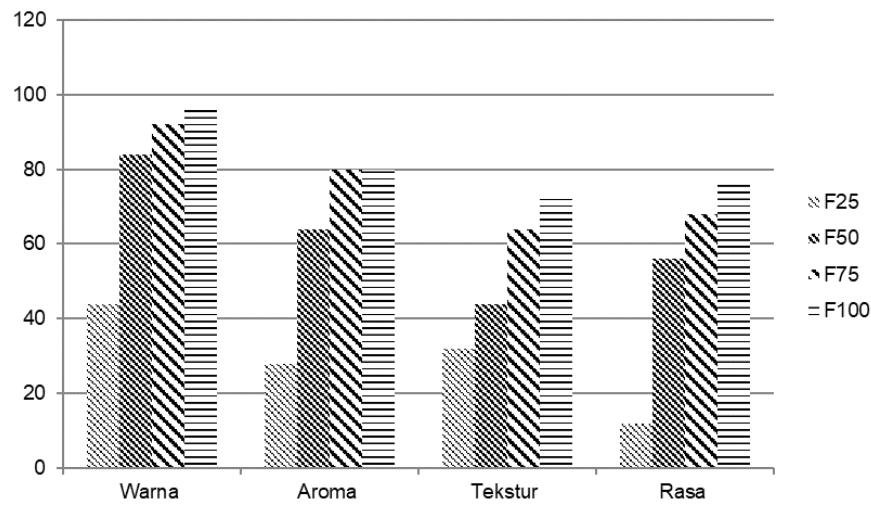

Figure 1. The illustration of percentage of panellists that gives the acceptance rate of breadfruit cookies based on colour, odour, texture, and flavour with likes category

Table 2 describes the average rating of the cookie 
acceptability among the panellists. The 100\% formulation received the highest rating of all. We found that the rating was directly proportional to the breadfruit content. The Friedman test analysed preference categories: Extremely dislike, dislike, like, and extremely like. The panellists had also put the $100 \%$ formulation into the extremely like category.

Table 2. The average rating of the breadfruit cookies acceptability

\begin{tabular}{ccccc}
\hline Cookies & F25 & F50 & F75 & F100 \\
\hline Colour & $2.56 \pm 0.14$ & $3.20 \pm 0.15$ & $3.36 \pm 0.16$ & $3.36 \pm 0.16$ \\
Odour & $2.20 \pm 0.18$ & $2.96 \pm 0.16$ & $3.36 \pm 0.16$ & $3.36 \pm 0.16$ \\
Texture & $2.08 \pm 0.16$ & $3.36 \pm 0.16$ & $2.52 \pm 0.17$ & $2.08 \pm 0.15$ \\
Flavour & $1.76 \pm 0.15$ & $2.56 \pm 0.16$ & $2.96 \pm 0.19$ & $3.20 \pm 0.18$ \\
\hline
\end{tabular}

Figure 1 illustrates the acceptability of the breadfruit cookies according to the panellists. The number of panelists who like the taste, color, aroma and texture of cookies with $100 \%$ formula is more than other formulas.

Breadfruit cookies contained of $19.38-20.51 \%$ resistant starch, $13.55-16.60 \%$ amylose, an 83.39$86.44 \%$ amylopectin. The analyses in this study showed significant differences between resistant starch, amylose, and amylopectin content on the four breadfruit cookies formulations. The highest resistant starch content was found in the $100 \%$ breadfruit flour, while the lowest one was in the $25 \%$ breadfruit flour. The low content of amylose in the cookies can influence the low content of resistant starch in breadfruit. Amylose content which is relatively low in the cookies with $25 \%$ of breadfruit flour caused no increase in resistant starch in cookies.

The production of resistant starch through retrogradation is more natural to occur in foods containing high amylose (Herawati, 2011). It is because amylose has a straight-chain structure, quickly graded, and when amylose chain rejoin to form a polymer compact and difficult to be hydrolysed by the digestive enzymes (Dewi and Isnawati, 2013). The retrogradation of amylose produces type 3 resistant starch (FuentesZaragoza et al., 2010). It is one of resistant starch formed from starch retrogradation, for example, due to processing and cooling (Herawati, 2011). The retrogradation is also desirable in terms of nutritional significance, due to the slower enzymatic digestion of retrograded starch and moderated release of glucose into the bloodstream (Wang and Copeland, 2013).

Amylose content on the cookies with $25 \%$ breadfruit flour was in a low category, according to amylose classification in which $10-15 \%$ is low, $>15 \%$ is moderate, and $>20 \%$ is high (Indrasari et al., 2008). According to the result from the by-difference calculation, the amylopectin content in the cookies varied, ranging from 83.39 to $86.44 \%$.
Factors that affect resistant starch content in the breadfruit cookies are the ratio of amylose and amylopectin content and the cookie preparation process. In general, cookies will go through a heating (roasting) process before consumption. The heating process can cause the starch to gelatinise, and if it continues throughout the cooling process, it will cause retrogradation. Retrogradation is a change in gelatinised starch during the cooling process. Gelatinisation and retrogradation will affect the digestibility of the starch in the intestine. The affected starch cannot be digested completely in the human intestine, causing the formation of digestive-resistant starch or resistant starch (Septianingrum et al., 2016).

Resistant starch is a form of starch that is unable to be digested by the digestive enzymes and resistant to gastric acid, and therefore it can reach colon to be fermented by probiotics. Resistant starch may also act as prebiotics in comparison to FOS and inulin. It has the ability to bind and maintain the water level in faeces, so it can prevent constipation when consumed in a large amount (Septianingrum et al., 2016). Furthermore, it also has other psychological effects such as maintaining intestinal and colon health, controlling GI in the blood and insulin response, providing satiety and decreasing energy intake, and improve lipid profiles in the blood (Lapu and Telussa, 2013). The process of resistant starch metabolism occurs within 5-7 hours after consumption; thus, it can lower postprandial blood sugar and insulinaemia (Ajani et al., 2012).

Retrogradation process of amylose can increase the content of resistant starch in food. Other than that, amylose is also beneficial for individuals with DM. Studies show that high amylose diet can reduce blood sugar level and insulin response curve due to its unbranched and compact structure compared to amylopectin (Behall and Howe, 1995). Therefore, it needs a longer time to digest, resulting in a lower blood sugar level compared to consuming food with high amylopectin content (Siagian, 2004; Gropper et al., 2009).

A previous study showed that breadfruit flour has a GI of 59, which is lower than the GI of rice (Fkr et al., 2011). This is beneficial to control blood sugar level as GI is a food indicator based on its effect on blood sugar level. The GI refers to a term that describes how fast the food affects blood sugar level after consumption. This study reveals that the cookies made from breadfruit flour had high resistant starch content that is resistant to hydrolysis of digestive enzymes due to its structure and granules. Increasing blood glucose level can interfere accordingly. Therefore, the higher resistant starch the food contains the lower its GI. 
Consuming $20 \mathrm{~g}$ of resistant starch per day can improve insulin sensitivity in male diabetics (S Landon et al., 2012). Food Agriculture Organization (FAO) recommends the consumption of 15-20 g of resistant starch per day to feel the benefits. This study shows that $100 \mathrm{~g}$ cookies with $100 \%$ breadfruit flour contain $20.51 \mathrm{~g}$ of resistant starch. Therefore, consuming $100 \mathrm{~g}$ of the cookies can be recommended to individuals with DM. However, this is not the upper limit of consumption. The consumption limit of resistant starch for them is not yet found. A study shows that higher consumption of resistant starch leads to a better improvement of insulin sensitivity in diabetics (Rosida and Yulistyani, 2013). Thus, breadfruit cookies consumption can be increased. However, we should also take the amount of staple food consumed into account. Another research analysing resistant starch in snack bars from various sorghum showed that it only contained $7.88-8.44 \%$ of resistant starch (Fathurrizqiah and Panunggal, 2015). The breadfruit cookies in this study had higher resistant starch content (19.38-20.51\%) compared to the sorghum snack bar.

Based on the odour, cookies with $100 \%$ breadfruit flour content are more preferred than other cookies. This could be due to its high amylose content compared to the other cookies. Amylose has high water absorption. As a result, the higher its ability to absorb water, the ability of flour to absorb fat will be lower. If less fat absorbed, the peroxide formation during roasting at high temperatures will be prevented, thus reducing rancidity (Simamora et al., 2014). Similarly, $100 \%$ breadfruit flour cookies received the highest rating on the texture acceptability level. The density of breadfruit flour cookies is believed to play a part to make the cookies crunchier.

In terms of taste acceptability, the $100 \%$ formulation received the highest rating compared to the others. Breadfruit flour has a typical flavour compared to other flour commonly used in cookies making. Tastes perceived by the gustatory system are divided into four categories: salty, sweet, bitter and sour. The substances in food dissolved and captured by the taste buds before sending a signal to the brain to recognise each taste. Although the cookies with $100 \%$ breadfruit flour got the highest rating among the other cookies, many panellists commented that the cookies were not sweet enough, this is due to the small amount of sweetener added to the cookies.

This study shows that cookies with $100 \%$ breadfruit flour content are the best one. Based on the data analysis from the colour acceptability test, the cookies with $75 \%$ and $100 \%$ breadfruit flour are more attractive and less pale compared to the others. The cookies with $75 \%$ breadfruit flour had a similar colour with the $100 \%$ ones. Breadfruit flour cannot precisely resemble wheat flour in terms of the final product colour. However, since the breadfruit flour has a slightly brown colour, it makes the colour of the cookies more attractive and less pale.

Breadfruit flour can be processed into a variety of products, including cakes, cookies, tart, bread and other products. Breadfruit flour can also replace wheat flour up to $100 \%$ ( $F k r$ et al., 2011). Chiffon cake made from $100 \%$ breadfruit flour has excellent acceptability in terms of texture, aroma and taste because the breadfruit has a unique taste and aroma compared to wheat flour (Sari et al., 2015). This study also confirms this finding, showing that the acceptability of the cookies with $100 \%$ breadfruit flour content got the highest rating and preferred by panellists in terms of odour, taste, texture and colour. The cookies made from the breadfruit flour has indeed a slightly more brownish colour compared to cookies made with wheat flour. However, this actually what makes the cookies distinctive and more attractive for the consumers to try.

\section{Conclusion}

Breadfruit cookies made from $100 \%$ breadfruit flour can be an alternative snack for individuals with DM. Based on our experiments, the four breadfruit cookie formulations have different resistant starch, amylose and amylopectin contents. The highest content of resistant starch and amylose was found in cookies with $100 \%$ breadfruit flour, while the lowest is in the $25 \%$ composition. The highest amylopectin content was found in the $25 \%$ formulation, and the lowest was in the $100 \%$ formulation. In contrast, the results of the hedonic test indicated that the cookies made from $100 \%$ breadfruit flour were the most accepted cookies by panellists in terms of odour, colour, texture and taste.

\section{Conflict of interest}

The authors declare no conflict of interest.

\section{Acknowledgments}

The author would like to thank all those who have helped this research to be done properly.

\section{References}

Adinugraha, H.A. and Kartikawati, N.K. (2012). Variasi Morfologi dan Kandungan Gizi Buah Sukun Variation on Morphology and Nutrients Composition of Bread Fruit. Wana Benih, 13(2), 99-106.

Ajani, A.O., Oshundahunsi, O.F., Rahman, A., Kayode, A.A., Aderibigbe, A. and Patricia, O.P. (2012). 
Proximate Composition and Sensory Qualities of Snacks Produced from Breadfruit Flour. Global Journal of Science Frontier Research, 12, 7-C

American Diabetes Association. (2011). Diagnosis and Classification of Diabetes Mellitus. Diabetes Journals, 34(Supplement 1), S62-S69. https:// doi.org/10.2337/dc11-S062

Behall, K.M. and Howe, J.C. (1995). Effect of long-term consumption of amylose vs amylopectin starch on metabolic variables in human subjects. The American Journal of Clinical Nutrition, 61(2), 334340. https://doi.org/10.1093/ajcn/61.2.334

Dewi, A.P. and Isnawati, M. (2013). Pengaruh Nasi Putih Baru Matang dan Nasi Putih Kemarin (Teretrogradasi) terhadap Kadar Glukosa Darah Postpandrial pada Subjek Wanita Pra Diabetes. Journal of Nutrition College, 2(3), 411-418. [In Bahasa Indonesia]. https://doi.org/10.14710/ jnc.v2i3.3443

Dewi, F.K., Suliasih, N. and Garnida, Y. (2010). Pembuatan Cookies dengan Penambahan Tepung Daun Kelor (Moringa oleifera) pada Berbagai Suhu Pemanggangan. Universitas Pasundan. [In Bahasa Indonesia].

Fathurrizqiah, R. and Panunggal, B. (2015). Kandungan Pati Resisten, Amilosa, dan Amilopektin Snack Bar Sorgum sebagai Alternatif Makanan Selingan bagi Penderita Diabetes Mellitus Tipe 2. Journal of Nutrition College, 4(4), 562-569. https:// doi.org/10.14710/jnc.v4i4.10163

Fkr, R., Rimbawan, R. and Amalia, L. (2011). Nilai Indeks Glikemik berbagai Produk Olahan Sukun (Artocarpus altilis). Jurnal Gizi Dan Pangan, 6(1), 28-35. [In Bahasa Indonesia]. https:// doi.org/10.25182/jgp.2011.6.1.28-35

Fuentes-Zaragoza, E., Riquelme-Navarrete, M.J., Sánchez-Zapata, E. and Pérez-Álvarez, J.A. (2010). Resistant starch as functional ingredient: A review. Food Research International, 43(4), 931-942. https://doi.org/10.1016/j.foodres.2010.02.004

Gropper, S.S., Smith, J.L. and Groff, J.L. (Eds.) (2009). Carbohydrates. In Advanced Nutrition and Human Metabolism. $5^{\text {th }}$ ed. USA: Wadsworth Publishing.

Herawati, H. (2011). Potensi Pengembangan Produk Pati Tahan Cerna Sebagai Pangan Fungsional. Balai Pengkajian Teknologi Pertanian Jawa Tengah. Jurnal Penelitian Dan Pengembagan Pertanian, 30 (1), 31-39. [In Bahasa Indonesia].

Indrasari, S.D., Purwani, E.Y. and Wibowo, P. (2008). Nilai Indeks Glikemik Beras Beberapa Varietas Padi. Penelitian Pertanian Tanaman Pangan, 27(3), 8. [In Bahasa Indonesia].
International Diabetes Federation (IDF). (2012). Clinical Guidelines Task Force Global Guidelines for Type 2 Diabetes., p. 72-82. Belgium: International Diabetes Federation (IDF).

Kementerian Kesehatan RI. (2013). Riset Kesehatan Dasar 2013 (RISKESDAS 2013). Indonesia: Kementerian Kesehatan Republik Indonesia. [In Bahasa Indonesia].

Kementerian Kesehatan RI. (2018). Riset Kesehatan Dasar 2018 (RISKESDAS 2018). Indonesia: Kementerian Kesehatan Republik Indonesia. [In Bahasa Indonesia].

Lapu, P. and Telussa, I. (2013). Analyzed the Resistant Starch Content of Some Types of Sago Starch In Embarrassment with Heating Temperature Variations. Indonesian Journal of Chemical Research, 1(1), 6-14.

Landon, S., Colyer, C.G.B. and Salman, H. (2012). The Resistant Starch Report. An Australian update on health benefits, measurement and dietary intakes. Australia: Goodman Fielder Ltd and National Starch Ltd.

Wild, S., Roglic, G., Green, A. and King, H. (2004). Global Prevalence of Diabetes. Diabetes Care, 27 (5), 1047-1053. https://doi.org/10.2337/ diacare.27.5.1047

Sari, N.M.E., Ni Wayan Sukerti, S.P. and Luh Masdarini, S.P. (2015). Pemanfaatan Tepung Sukun menjadi Chiffon Cake. Jurnal BOSAPARIS: Pendidikan Kesejahteraan Keluarga, 3, 4850. [In Bahasa Indonesia]. https://doi.org/10.23887/ jjpkk.v3i1.4850

Septianingrum, E., Liyanan, L. and Kusbiantoro, B. (2016). Review Indeks Glikemik Beras: FaktorFaktor yang Mempengaruhi dan Keterkaitannya terhadap Kesehatan Tubuh. Jurnal Kesehatan, 1(1), 1-9. [In Bahasa Indonesia]. https://doi.org/10.23917/ jurkes.v9i1.3434

Siagian, R. (2004). Faktor Faktor yang Mempengaruhi Indeks Glikemik Pangan, Indeks Glikemik dan Beban Glikemik Beberapa Jenis Pangan Indeks Glikemik Pangan: Cara Mudah Memilih Pangan yang Menyehatkan. Jakarta: Penebar Swadaya. [In Bahasa Indonesia].

Simamora, A.S.K.Y., Suhaidi, I. and Yusraini, E. (2014). Pengaruh Lama Pengeringan Kentang Dan Perbandingan Tepung Terigu Dan Tepung Kentang Terhadap Mutu Cookies Kentang. Jurnal Rekayasa Pangan dan Pertanian, 2(3), 1-10. [In Bahasa Indonesia].

Siti Nuriah, M.N., Zarinah, Z. and Napisah, H. (2018). Comparative studies of the physicochemical and 
pasting properties of Malaysian breadfruit (Artocarpus altilis) flour and commercial wheat flour presented at the International Conference on Agriculture, Animal Sciences and Food Technology 30-31 October 2018. Terengganu, Malaysia: Universiti Sultan Zainal Abidin.

Rosida. and Yulistyani, R. (2013). Pengaruh Proses Pengolahan terhadap Kadar Pati Resisten Sukun (Artocarpus altilis Park). Jurnal Teknologi Pangan, 5(1), 55-63. [In Bahasa Indonesia].

Turi, C.E., Liu, Y., Ragone, D. and Murch, S.J. (2015). Breadfruit (Artocarpus altilis and hybrids): A traditional crop with the potential to prevent hunger and mitigate diabetes in Oceania. Trends in Food Science and Technology, 45(2), 264-272. https:// doi.org/10.1016/j.tifs.2015.07.014

Wang, S. and Copeland, L. (2013). Molecular disassembly of starch granules during gelatinization and its effect on starch digestibility: A review. Food and Function, 4(11), 1564-1580.. https:// doi.org/10.1039/c3fo60258c

World Health Organization (WHO). (2016). Diabetes. Retrieved from WHO website: https://www.who.int/ news-room/fact-sheets/detail/diabetes

Zarinah, Z. Farah, S.R., Norshazila, S. and Napisah, H. (2018). Glycemic index and sensory evaluation of breadfruit resistant presented at the International Conference on Agriculture, Animal Sciences and Food Technology 30-31 October 2018. Terengganu, Malaysia: Universiti Sultan Zainal Abidin. 